Published in final edited form as:

J Allergy Clin Immunol Pract. 2018 ; 6(1): 22-29. doi:10.1016/j.jaip.2017.10.002.

\title{
School Environmental Intervention Programs
}

\author{
Perdita Permaul, MD ${ }^{a, b}$ and Wanda Phipatanakul, MD, MS \\ aMassachusetts General Hospital for Children, Division of Pediatric Allergy and Immunology \\ bHarvard Medical School \\ 'Boston Children's Hospital, Division of Allergy and Immunology
}

\begin{abstract}
Exposure to indoor allergens and pollutants play a significant part in the development of asthma and its associated morbidity. Inner-city children with asthma are disproportionately affected by these exposures with increased asthma morbidity. While years of previous research have linked exposures in the urban home environment with significant childhood asthma disease, many of these allergens are also present in inner-city school environments. Therefore, evaluation of the school environment of patients with asthma is also essential. School-based environmental interventions may offer benefit for this problem and has the potential to help many children with asthma at once in a cost-effective manner. It is important that environmental health researchers continue to assess which interventions are most practical and result in the greatest measurable improvements.
\end{abstract}

\section{Keywords}

asthma; environment; allergen; pollutant; inner-city; home; school; intervention; integrated pest management

\section{Background}

Exposure to indoor allergens and pollutants play a significant part in the development of atopic diseases, including asthma, allergic rhinitis, and atopic dermatitis. The degree of exposure to environmental allergens in addition to the atopic genetic predisposition of the individual influences the development of $\operatorname{IgE}$ (sensitization) and $\mathrm{Th}_{2}$ responses. Classically, allergens cross-link preformed IgE on mast cells which leads to recruitment of $\mathrm{Th}_{2}$ cells,

\footnotetext{
Corresponding Author: Wanda Phipatanakul, MD, MS, Division of Allergy and Immunology, Boston Children's Hospital, 300 Longwood Avenue, Fegan Building, $6^{\text {th }}$ Floor, Boston, MA 02115 Wanda.Phipatanakul@ childrens.harvard.edu, Telephone: 617-355-6117, Fax: 617-730-0248.

Author Contact Information: Perdita Permaul, MD, Division of Pediatric Allergy and Immunology, Massachusetts General Hospital for Children, 175 Cambridge Street, $5^{\text {th }}$ Floor, Boston, MA 02114, ppermaul@mgh.harvard.edu

Disclosure Statement: All authors have no direct financial interest in subject matter or materials discussed in article or with a company making a competing product.

Publisher's Disclaimer: This is a PDF file of an unedited manuscript that has been accepted for publication. As a service to our customers we are providing this early version of the manuscript. The manuscript will undergo copyediting, typesetting, and review of the resulting proof before it is published in its final citable form. Please note that during the production process errors may be discovered which could affect the content, and all legal disclaimers that apply to the journal pertain.
} 
basophils, and eosinophils, resulting in immediate and late allergic responses. There may be other biologic functions of allergens, however, that play a direct role in causing allergic inflammation, such as the involvement of allergen proteases ${ }^{1}$ and the stimulation of pattern recognition receptors on epithelial cells, ${ }^{2}$ to name a few. Studies indicate that more than $80 \%$ of school age children with asthma are sensitized to at least one indoor allergen and that allergic sensitization is a strong predictor of disease persistence in later life. ${ }^{3,4}$ The timing of sensitization is also an important factor; Rubner and colleagues demonstrated that aeroallergen sensitization at younger ages was associated with an increased risk of asthma in later childhood. ${ }^{5}$ In addition, children are likely to become sensitized to the allergen that predominates in their local environment. Therefore, the effects of these individual allergens will vary depending on the socioeconomic status, weather, and geographical location, among the many factors.

While years of previous research have demonstrated the association between environmental exposures in the inner-city home environment and significant childhood asthma morbidity, 6-8 many of these allergens and pollutants are also present in urban school environments. ${ }^{9-11}$ This is noteworthy since children spend 7 to 12 hours per day in school and daycare settings, representing an occupational model for children. The common indoor allergens include house dust mites, cockroach, rodents, furry pets such as cat and dog, and molds. Previous studies have identified unique inner-city allergen exposures in homes and schools as important risk factors for asthma morbidity, ${ }^{8}, 12,13$ namely mouse and cockroach allergens, and demonstrated that interventions to reduce home exposure improve asthma outcomes. ${ }^{14}$ As such, several studies have investigated the effects of multifaceted intervention regimens in homes which include education, thorough cleaning, use of high-efficiency particulate arrestance (HEPA) filters, integrated pest management (IPM), and maintenance of these practices. ${ }^{14,15}$ The environment outside of the home, especially in the United States (U.S.), is less well understood though. Literature reviews have discussed the limited school-based environmental intervention studies to date in the U.S. and highlight the need for them. ${ }^{16-18}$ As a consequence, successful home-based strategies currently serve as the prototype for school-based environmental interventions.

In this article, we discuss common exposures encountered in schools, especially in urban areas where asthma morbidity and mortality is highest among children. ${ }^{19}$ We review the association between school environmental exposures and pediatric asthma morbidity. Additionally, we review school-based asthma management programs and environmental control and intervention strategies intended to improve asthma morbidity in the pediatric population.

\section{The Importance of Indoor Environmental Exposure Control}

The indoor environment is a significant reservoir of various exposures (allergens, pollutants, bacteria and viruses) with the ability to affect the development of asthma and its associated morbidity. This is supported by observational epidemiologic studies which identified earlylife allergen exposures as risk factors for early allergic sensitization and the subsequent development of asthma. ${ }^{20,21}$ It is difficult to know, however, whether environmental control methods have a role in the primary prevention of asthma; the results of several primary 
prevention trials have been mixed. ${ }^{3,22,23}$ Despite these findings, a Cochrane meta-analysis estimated that environmental control practices reduced the risk of current asthma by approximately $30-50 \%$ in children. ${ }^{24}$ Therefore, while primary prevention is a goal we hope to attain, controlling environmental asthma triggers is beneficial for those with current asthma.

It is important that patients with asthma take all the essential actions recommended to reduce their exposure to indoor environmental asthma triggers. ${ }^{25,} 26$ A priority message from the National Asthma Education and Prevention Program (NAEPP) Expert Panel Report 3 guidelines for the management of asthma is that for any patient with persistent asthma, the clinician should: 1) identify allergen exposures; 2) use skin testing or in vitro testing to assess specific sensitivities to indoor allergens; and 3) implement environmental controls to reduce exposure to relevant allergens. ${ }^{27}$ Healthcare providers have a responsibility to ask about environmental exposures and to ensure that patients have the knowledge and resources to implement environmental control measures. Low-cost environmental interventions are a reasonable first start with costly interventions reserved for after an allergy consultation is completed. Strategies for allergen avoidance should include a comprehensive targeted environmental control strategy which takes into account the patient's sensitizations and exposures. It should be considered the first line of therapy for patients with indoor allergen sensitivities.

While the home environment is important, consideration should be given to other places where the child spends time such as schools and daycares. It has been shown that schools can be a source of allergen exposure connected to asthma morbidity. ${ }^{12}$ School-based environmental interventions may offer benefit for this problem and has the potential to help many children with asthma at once. A U.S. school-based environmental intervention study is currently underway to help answer this question, employing pest management techniques and high efficiency particulate arrestance (HEPA) air filters. ${ }^{28}$

\section{The School Environment}

\section{Indoor Allergens}

Historically, the prevalent allergens discovered in inner-city home environments have been cockroach and mouse allergen, ${ }^{8,29-33}$ both of which are also linked to higher asthma morbidity. ${ }^{8,} 34,35$ These findings have translated to the urban school environment in the U.S. where the majority of school studies examining cockroach and mouse allergen levels have been conducted. ${ }^{9}, 10,36,37$ The School Inner-City Asthma Study (SICAS) is a National Institute of Health (NIH) and National Institute of Allergy and Infectious Disease (NIAID) funded, comprehensive, prospective study of inner-city school and classroom-specific exposures and asthma morbidity among students in the Northeastern U.S., adjusting for home exposures. ${ }^{38}$ The SICAS results demonstrated substantial levels of mouse allergen in school classrooms compared to the same students' homes, ${ }^{10}$ with exposure to mouse allergen in schools associated with increased asthma symptoms and decreased lung function. ${ }^{12}$ Interestingly, cat and dog allergen levels were lower in these SICAS inner-city schools when compared to European school-based studies showing higher levels, likely due to passive transfer from students who owned pets in their homes. ${ }^{39,}{ }^{40}$ Levels of cockroach and 
dust mite allergens were undetectable to very low in SICAS dust samples from both schools and homes. In contrast, school-based studies performed in southeast Texas, Baltimore and Manchester, England found detectable levels of cockroach allergen in all schools, suggesting that cockroach allergen levels vary by location even within a city, by race/ ethnicity, and by gradation in poverty levels. ${ }^{41-43}$ Moreover, both cockroach and dust mites require high humidity and warmth to survive. This highlights how geographic, socioeconomic, climatic, and cultural differences might influence the prevalence of allergens in varying environments.

\section{Mold}

Classroom activity leading to resuspension of particles, inadequate building maintenance, poor ventilation, and ambient air pollution taken together lends itself to a distinctive microenvironment of indoor particles and pollutants on which mold and allergens can be carried. The Health Effects of Indoor Air Pollutants (HITEA) research group in Europe demonstrated high levels of mold in schools, especially those with moisture damage. ${ }^{44,45}$ These findings substantiate the results from the U.S. based SICAS, which found elevated levels of classroom mold in settled and airborne dust. ${ }^{46}$ The HITEA research group recently showed that the immunotoxicological potency of settled dust samples collected from European schools differs largely between geographical locations and is likely influenced by moisture damage of the school buildings. ${ }^{47}$ Further studies are needed to evaluate the association between immunotoxicological exposure from settled dust and respiratory health effects in children. Holst and colleagues showed that high classroom dampness in Danish schools was associated with increased wheezing and decreased spirometry in exposed students. ${ }^{48}$ A Taiwanese study illustrated that mold exposure in classrooms correlated with asthma symptoms and a relief of symptoms on weekends and holidays, further supporting an occupational model for children. ${ }^{49}$ In younger children, mold exposure in daycare centers was also associated with wheezing. ${ }^{50}$ Finally, new research provides evidence that exposure to a wide diversity of mold species may actually be protective against atopy development. ${ }^{51}$ In a recent study, Rufo et al. showed that classrooms with increased fungal diversity scores showed a significantly lower prevalence of children with atopic sensitization, but not asthma. ${ }^{52}$ More studies are needed to evaluate the role of fungal diversity on the development of allergic diseases.

\section{Endotoxin}

Endotoxin is a component found in the outer membranes of gram-negative bacteria. It is associated with the presence of pets, rodents, dampness and mold. Endotoxin exposure has been linked to airway inflammation, early wheezing and asthma morbidity. ${ }^{53,54}$ While the majority of studies have evaluated the effects of home and occupational endotoxin exposure on asthma, both U.S. and European school-based studies indicate that children with asthma are exposed to higher concentrations of endotoxin in their classrooms compared to home. 55,56, 57 Lai et al. demonstrated in the SICAS cohort that inner-city children with asthma are exposed to high levels of classroom airborne endotoxin levels. ${ }^{58}$ Moreover, after adjusting for home exposures, classroom endotoxin exposure was associated with an increase in asthma symptom days for children with non-atopic asthma. Alleviating school-related endotoxin exposures may be a way to lessen asthma morbidity in urban children. 


\section{Geographic Information System, Indoor Air Pollution and Air Quality}

A growing body of work demonstrates that concentrations of many pollutants are higher indoors than outdoors, ${ }^{59}$ and higher in urban settings when compared to rural ones. ${ }^{60}$ Unlike the home environment, schools have fewer indoor sources of pollutants since most schools don't have active cooking and smoking is prohibited. However, traffic pollution is an important source of particulate matter $(\mathrm{PM})$, nitrogen dioxide $\left(\mathrm{NO}_{2}\right)$ and black carbon which can penetrate indoors and adversely affect the indoor air quality of schools. ${ }^{61} \mathrm{Gaffin}$ et al. investigated the relationship of indoor to outdoor PM in the SICAS inner-city school classrooms. Using mixed effects linear models, they showed that the classroom was an important source of $\mathrm{PM}_{2.5}$ and that the penetration of outdoor $\mathrm{PM}_{2.5}$ particles varied by school. ${ }^{62}$ Another recent study from this group demonstrated that in children with asthma, indoor classroom $\mathrm{NO}_{2}$ exposure was highly associated with an increase in airflow obstruction. ${ }^{63}$ Other factors fueling the poor indoor air quality of schools are reduced ventilation, ${ }^{64,65}$ inadequate building maintenance, ${ }^{66}$ and exposure to janitorial cleaning products and the by-products of heating and cooling systems. The relationship between air pollution and asthma morbidity in children is well established. ${ }^{67}$ Exposure to indoor pollutants is independently associated with increased respiratory symptoms and rescue asthma medication use in urban children with asthma. ${ }^{68}$

In recent years, the ability to locate residences in space and obtain geocodable health data coupled with the use of geographic information system (GIS) has given researchers the enhanced ability to link exposure information to individual addresses. Most environmental exposure and health studies in patients with asthma use exposures averaged over the course of a day and do not take into account the spatial/temporal variability that likely occurs as a person moves from home, into transportation, and then school and work microenvironments. For instance, schools are typically centrally located within a community in close proximity to highways, heavy traffic routes, and commercial and industrial buildings. School locations also serve as a site for drop-off/pick-up, idling of cars, bus stops, potentially contributing to an increase in ambient air pollution. Kingsley et al. showed that approximately 3.2 million (6.5\%) children across the United States attended schools located within 100 meters of a major roadway defined by the United States Census Bureau. ${ }^{69}$ Air pollutants that are found near busy roads as a product of traffic exhaust, such as $\mathrm{NO}_{2}$ and $\mathrm{PM}$, have been shown to be associated with respiratory illness in children, ${ }^{70,71}$ and the use of GIS has provided evidence that living in proximity to traffic increases the incidence of asthma ${ }^{72}$ and risk of exacerbations in both children and adults. ${ }^{73}$

\section{School-Based Asthma Management Programs}

A number of national, state, and city governmental organizations such as the American Lung Association, Allergy and Asthma Foundation of America, National Heart, Blood and Lung Institute, the Center for Disease Control and Prevention's National Asthma Control Program, and the U.S. Environmental Protection Agency (EPA) have developed a number of school-based asthma programs. The EPA created the Indoor Air Quality Tools for Schools Program with the aim of improving environmental conditions in schools. It provides recommended actions for teachers, facilities staff and school officials such as keeping 
ventilation units in classrooms free of clutter, reducing the number of items made of cloth in the classroom, removing classroom pets that cause allergic reactions or trigger asthma attacks in students, and reporting maintenance problems in classrooms immediately. These measures should be taken until more widespread multifaceted school intervention strategies are implemented. Additionally, the School-Based Asthma Management Program $\left(\text { SAMPRO }^{\mathrm{TM}}\right)^{74}$ and the Centers for Disease Control and Prevention (CDC) Healthy Schools Program offer toolkits to schools. These toolkits help to develop asthma-friendly schools that provide appropriate school health services for students with asthma and a safe and healthy school environment to reduce asthma triggers. Moreover, it has been shown that state asthma programs play an important role in implementing multi-component, schoolbased asthma interventions due to their access to statewide asthma surveillance data, ability to translate policies into action, provide resources, and form connections between schools and community stakeholders. ${ }^{75}$

In addition to these programs, school-based health centers (SBHCs) have been created to provide an ideal setting in which to incorporate environmental components into existing chronic disease programs. There are over 2,000 SBHCs throughout the country serving an ethnically diverse population of more than 2 million children, primarily in low-income areas. A large number of these centers offer asthma management. SBHC staff members can play a role in maintaining healthy indoor environments in school by increasing awareness, facilitating an indoor air quality assessment, or implement specific interventions to address mold, dust mites, pests, pets, and ventilation.

\section{Environmental Control and Intervention Strategies in Schools}

There is a paucity of thorough data on school-based environmental interventions and health outcomes; the few studies that have been published are small and not adequately powered to comprehensively assess asthma morbidity outcomes and are summarized in Table I. ${ }^{76-81}$ In an effort to reduce pet dander in schools, dedicated school clothing and banning pet ownership in Swedish schools showed that airborne cat allergen levels were on average 4-6 times lower in classes with school clothing or pet ownership ban compared with control classes. ${ }^{81}$ This particular school environmental intervention strategy may not be practical in the U.S., however. Other allergen avoidance measures such as removal of upholstery and curtains, increased cleaning, and replacement of bookshelves with cupboards to lessen allergen load offered no significant change in Swedish classroom cat allergen levels. ${ }^{82}$ There are 2 small longitudinal studies in Finland that showed improvement in asthma symptoms through reparation of air filtration systems and moisture damage in schools, and reduction in mold exposure and other building maintenance. ${ }^{79}, 80$ These studies are limited by the small number of schools that were studied. In one Australian school study, an intervention replacing unflued gas heaters with electric heaters effectively reduced $\mathrm{NO}_{2}$ levels and improved asthma symptoms. ${ }^{76}$

In a landmark study, Morgan and colleagues revealed that among inner-city children with atopic asthma, an individualized, home-based, multifaceted environmental intervention decreased exposure to indoor allergens, including cockroach and dust-mite allergens, leading to decreased asthma morbidity. ${ }^{14}$ As such, several studies have investigated the effects of 
multifaceted intervention regimens which include education, thorough cleaning, use of HEPA filters, integrated pest management, and maintenance of these practices. ${ }^{14,15,83}$ The term "multifaceted" has been used to describe interventions directed toward more than one asthma trigger or interventions with more than one component. Given the paucity of comprehensive data on school-based environmental interventions and health outcomes, these successful home-based strategies currently serve as the model for school-based interventions. For instance, the use of air filtration systems to reduce environmental exposures is a potential school-based intervention. ${ }^{84}$ One pilot study showed that HEPA air filters reduced mold spore counts in daycare centers by $50 \%{ }^{78}$

School environmental intervention studies that are prospective, longitudinal, randomized, double-blinded controlled trials using sham interventions as controls are needed as the majority of studies performed to date have been small and cross-sectional with no control for home exposures. $9,36,39,41-43,85,86$ Given the SICAS findings of high mouse allergen levels in school classrooms, ${ }^{10,12}$ a NIH/NIAID School Inner-City Asthma Intervention Study (ClinicalTrials.gov NCT02291302), (SICAS 2), using environmental control strategies modeled from successful home-based interventions, is underway with health outcomes results pending. ${ }^{28}$ This randomized, controlled trial is comprehensively evaluating the role of a school-based environmental intervention and is adequately powered to assess asthma outcomes, adjusting for home exposures. The research group conducted a pilot study prior to launching the main study and demonstrated that a classroom-based air cleaner intervention led to significant reductions in particulate matter with diameter of $<2.5 \mu \mathrm{m}$ and black carbon, compared to sham filters. ${ }^{77}$ The use of HEPA air filters to reduce indoor pollutant particles and its associated allergens is currently being studied in SICAS 2. Another feasible school-based intervention is IPM. IPM is a multidisciplinary approach that uses a range of pest control methods such as: 1) monitoring pest populations with sticky traps to find out where they are living and hiding (reservoirs); 2) blocking pest access and entryways; 3) eliminating food and water (facilitating factors); 4) selectively applying low-toxicity pesticides. Nalyanya and colleagues demonstrated that IPM implementation in select North Carolina schools was not only more effective at controlling cockroaches than conventional pest control but lead to long-term reductions in allergen concentrations. ${ }^{87}$

\section{Challenges of School Environmental Intervention Studies}

The school environment is a complex microenvironment of indoor allergens, pollutants, and particles with more potentially significant environmental exposures than in the home. The predominating environmental exposures in individual schools across the country will likely vary due to differing geographic, climate and socioeconomic conditions, and distance from major highways and roadways, among the many factors. Therefore, a single school environmental intervention strategy may not be realistic or generalizable for all schools, making the implementation of school environmental intervention strategies complicated. To adequately show improved asthma outcomes, these variable exposures need to be taken into consideration when designing school intervention studies. Studies suggest that environmental interventions are likely cost-effective but implementation and buy-in to do this necessary research in schools in order to prove its benefit is a challenge. ${ }^{88}$ However, while previous home intervention studies target a single individual or family, the school has 
the potential to intervene on a community of children, and if effective, should be much more cost-effective.

Other unique challenges include the logistics of implementing these interventions in a classroom setting in an unobtrusive way. For instance, HEPA filters need to be both physically and acoustically tolerable for students. While it is possible for some school-based interventions to be blinded, such as sham versus active filters in the classrooms, large-scale interventions might be more difficult to blind. In addition, certain interventions such as IPM cannot be randomized from classroom to classroom but could be randomized between schools. Lastly, and of paramount importance to the success of these school-based environmental intervention studies is the commitment and community buy-in from senior school administrators, principals, teachers, school nurses, facilities management, as well as the students and their families.

\section{Conclusions}

Environmental control measures can and should supplement good asthma medical care. As in home environments, it is unlikely that a single school or classroom-based environmental exposure is exclusively responsible for asthma morbidity, given that asthma involves a number of factors. Both home and school environmental control approaches taken together have the ability to optimize asthma health outcomes, understanding that this approach might be more cost prohibitive. Our SICAS 2 study is attempting to focus on comprehensively evaluating school-specific environmental interventions and health outcomes, adjusting for exposure in the home as an initial step. From a public health perspective, the school environment could be considered as a target for primary and secondary prevention of allergic disorders including asthma. While it is more practical and cost-effective to perform environmental interventions on a single school affecting many children at once than the many individual homes in a community, there are challenges with designing school intervention studies to target the vast environmental exposures across schools in the U.S. in a meaningful way to improve asthma outcomes and there are the prohibitive costs associated with these studies.. It is important that environmental health researchers continue to assess which school environmental interventions are most practical and result in the greatest measurable improvements. Furthermore, research should further examine the relationship between allergen exposure in schools and resulting health effects, in order to develop an accurate exposure-risk model specific to the school environment.

\section{Acknowledgments}

Funding Source: This work was supported by grants K24 AI 106822, R01 HL 137192, U01 AI 110397, and U01 AI 126614 (PI: Dr. Phipatanakul), and K23 AI 123517 (PI: Dr. Permaul) from the National Institutes of Health.

This work was also supported in part from the Allergy and Asthma Awareness Initiative, Inc.

\section{Abbreviations}

$\begin{array}{ll}\text { IgE } & \text { Immunoglobulin E } \\ \text { Th2 }_{2} & \text { T helper 2 }\end{array}$


HEPA high efficiency particulate arrestance

IPM integrated pest management

NAEPP National Asthma Education and Prevention Program

SICAS School Inner-City Asthma Study

NIH National Institutes of Health

NIAID National Institute of Allergy and Infectious Disease

HITEA The Health Effects of Indoor Air Pollutants

PM particulate matter, $\mathrm{NO}_{2}$, nitrogen dioxide

GIS geographic information system

EPA Environmental Protection Agency

SAMPRO School-Based Asthma Management Program

CDC Centers for Disease Control and Prevention

SBHC school-based health centers

\section{References}

1. Chapman MD, Wünschmann S, Pomés A. Proteases as Th2 adjuvants. Curr Allergy Asthma Rep. 2007; 7(5):363-7. [PubMed: 17697645]

2. Trompette A, Divanovic S, Visintin A, Blanchard C, Hegde RS, Madan R, Thorne PS, Wills-Karp M, Gioannini TL, Weiss JP, Karp CL. Allergenicity resulting from functional mimicry of a Toll-like receptor complex protein. Nature. 2009; 457(7229):585-8. [PubMed: 19060881]

3. Sporik R, Holgate ST, Platts-Mills TA, Cogswell JJ. Exposure to house-dust mite allergen (Der p I) and the development of asthma in childhood. A prospective study. N Engl J Med. 1990; 323(8):5027. [PubMed: 2377175]

4. Illi S, von Mutius E, Lau S, Niggemann B, Grüber C, Wahn U. group MASM. Perennial allergen sensitisation early in life and chronic asthma in children: a birth cohort study. Lancet. 2006; 368(9537):763-70. [PubMed: 16935687]

5. Rubner FJ, Jackson DJ, Evans MD, Gangnon RE, Tisler CJ, Pappas TE, Gern JE, Lemanske RF. Early life rhinovirus wheezing, allergic sensitization, and asthma risk at adolescence. J Allergy Clin Immunol. 2017; 139(2):501-507. [PubMed: 27312820]

6. Kattan M, Mitchell H, Eggleston P, Gergen P, Crain E, Redline S, Weiss K, Evans R, Kaslow R, Kercsmar C, Leickly F, Malveaux F, Wedner HJ. Characteristics of inner-city children with asthma: the National Cooperative Inner-City Asthma Study. Pediatr Pulmonol. 1997; 24(4):253-62. [PubMed: 9368259]

7. Crain EF, Walter M, O'Connor GT, Mitchell H, Gruchalla RS, Kattan M, Malindzak GS, Enright P, Evans R, Morgan W, Stout JW. Home and allergic characteristics of children with asthma in seven U.S. urban communities and design of an environmental intervention: the Inner-City Asthma Study. Environ Health Perspect. 2002; 110(9):939-45. [PubMed: 12204830]

8. Rosenstreich DL, Eggleston P, Kattan M, Baker D, Slavin RG, Gergen P, Mitchell H, McNiffMortimer K, Lynn H, Ownby D, Malveaux F. The role of cockroach allergy and exposure to cockroach allergen in causing morbidity among inner-city children with asthma. N Engl J Med. 1997; 336(19):1356-63. [PubMed: 9134876] 
9. Chew GL, Correa JC, Perzanowski MS. Mouse and cockroach allergens in the dust and air in northeastern United States inner-city public high schools. Indoor Air. 2005; 15(4):228-34. [PubMed: 15982269]

10. Permaul P, Hoffman E, Fu C, Sheehan W, Baxi S, Gaffin J, Lane J, Bailey A, King E, Chapman M, Gold D, Phipatanakul W. Allergens in urban schools and homes of children with asthma. Pediatr Allergy Immunol. 2012; 23(6):543-9. [PubMed: 22672325]

11. Salo PM, Sever ML, Zeldin DC. Indoor allergens in school and day care environments. J Allergy Clin Immunol. 2009; 124(2):185-92. 192.e1-9. quiz 193-4. [PubMed: 19577284]

12. Sheehan WJ, Permaul P, Petty CR, Coull BA, Baxi SN, Gaffin JM, Lai PS, Gold DR, Phipatanakul W. Association Between Allergen Exposure in Inner-City Schools and Asthma Morbidity Among Students. JAMA Pediatr. 2017; 171(1):31-38. [PubMed: 27893060]

13. Grant T, Aloe C, Perzanowski M, Phipatanakul W, Bollinger ME, Miller R, Matsui EC. Mouse Sensitization and Exposure Are Associated with Asthma Severity in Urban Children. J Allergy Clin Immunol Pract. 2017; 5(4):1008-1014.e1. [PubMed: 27923647]

14. Morgan WJ, Crain EF, Gruchalla RS, O'Connor GT, Kattan M, Evans R, Stout J, Malindzak G, Smartt E, Plaut M, Walter M, Vaughn B, Mitchell H. Group I-CAS. Results of a home-based environmental intervention among urban children with asthma. N Engl J Med. 2004; 351(11): 1068-80. [PubMed: 15356304]

15. Pongracic JA, Visness CM, Gruchalla RS, Evans R, Mitchell HE. Effect of mouse allergen and rodent environmental intervention on asthma in inner-city children. Ann Allergy Asthma Immunol. 2008; 101(1):35-41. [PubMed: 18681082]

16. Huffaker M, Phipatanakul W. Introducing an environmental assessment and intervention program in inner-city schools. J Allergy Clin Immunol. 2014; 134(6):1232-1237. [PubMed: 25441649]

17. Hauptman M, Phipatanakul W. Recent advances in environmental controls outside the home setting. Curr Opin Allergy Clin Immunol. 2016; 16(2):135-41. [PubMed: 26859366]

18. Hauptman M, Phipatanakul W. The school environment and asthma in childhood. Asthma Res Pract. 2015; 1(12):1-7. [PubMed: 27965756]

19. Gergen PJ, Togias A. Inner city asthma. Immunol Allergy Clin North Am. 2015; 35(1):101-14. [PubMed: 25459579]

20. Sly PD, Boner AL, Björksten B, Bush A, Custovic A, Eigenmann PA, Gern JE, Gerritsen J, Hamelmann E, Helms PJ, Lemanske RF, Martinez F, Pedersen S, Renz H, Sampson H, von Mutius E, Wahn U, Holt PG. Early identification of atopy in the prediction of persistent asthma in children. Lancet. 2008; 372(9643):1100-6. [PubMed: 18805338]

21. Litonjua AA, Milton DK, Celedon JC, Ryan L, Weiss ST, Gold DR. A longitudinal analysis of wheezing in young children: the independent effects of early life exposure to house dust endotoxin, allergens, and pets. J Allergy Clin Immunol. 2002; 110(5):736-42. [PubMed: 12417882]

22. Woodcock A, Lowe LA, Murray CS, Simpson BM, Pipis SD, Kissen P, Simpson A, Custovic A. Group NMAaAS. Early life environmental control: effect on symptoms, sensitization, and lung function at age 3 years. Am J Respir Crit Care Med. 2004; 170(4):433-9. [PubMed: 15142868]

23. Toelle BG, Garden FL, Ng KK, Belousova EG, Almqvist C, Cowell CT, Tovey ER, Webb KL, Leeder SR, Marks GB, Team CAPS. Outcomes of the childhood asthma prevention study at 11.5 years. J Allergy Clin Immunol. 2013; 132(5):1220-1222.e3. [PubMed: 23900055]

24. Maas T, Kaper J, Sheikh A, Knottnerus JA, Wesseling G, Dompeling E, Muris JW, van Schayck CP. Mono and multifaceted inhalant and/or food allergen reduction interventions for preventing asthma in children at high risk of developing asthma. Cochrane Database Syst Rev. 2009;

(3):CD006480. [PubMed: 19588394]

25. Matsui EC, Abramson SL, Sandel MT. IMMUNOLOGY SOAA, HEALTH COE. Indoor Environmental Control Practices and Asthma Management. Pediatrics. 2016; 138(5)

26. Gold DR, Adamkiewicz G, Arshad SH, Celedón JC, Chapman MD, Chew GL, Cook DN, Custovic A, Gehring U, Gern JE, Johnson CC, Kennedy S, Koutrakis P, Leaderer B, Mitchell H, Litonjua AA, Mueller GA, O'Connor GT, Ownby D, Phipatanakul W, Persky V, Perzanowski MS, Ramsey CD, Salo PM, Schwaninger JM, Sordillo JE, Spira A, Suglia SF, Togias A, Zeldin DC, Matsui EC. NIAID, NIEHS, NHLBI, and MCAN Workshop Report: The indoor environment and childhood 
asthma-implications for home environmental intervention in asthma prevention and management. $\mathrm{J}$ Allergy Clin Immunol. 2017

27. Program NAEaP. Expert Panel Report 3 (EPR-3): Guidelines for the Diagnosis and Management of Asthma-Summary Report 2007. J Allergy Clin Immunol. 2007; 120(5 Suppl):S94-138. [PubMed: 17983880]

28. Phipatanakul W, Koutrakis P, Coull BA, Kang CM, Wolfson JM, Ferguson ST, Petty CR, Samnaliev M, Cunningham A, Sheehan WJ, Gaffin JM, Baxi SN, Lai PS, Permaul P, Liang L, Thorne PS, Adamkiewicz G, Brennan KJ, Baccarelli AA, Gold DR. The School Inner-City Asthma Intervention Study: Design, rationale, methods, and lessons learned. Contemp Clin Trials. 2017; 60:14-23. [PubMed: 28619649]

29. Ahluwalia SK, Peng RD, Breysse PN, Diette GB, Curtin-Brosnan J, Aloe C, Matsui EC. Mouse allergen is the major allergen of public health relevance in Baltimore City. J Allergy Clin Immunol. 2013; 132(4):830-5. e1-2. [PubMed: 23810154]

30. Phipatanakul W, Eggleston PA, Wright EC, Wood RA. Mouse allergen. I. The prevalence of mouse allergen in inner-city homes. The National Cooperative Inner-City Asthma Study. J Allergy Clin Immunol. 2000; 106(6):1070-4. [PubMed: 11112888]

31. Gruchalla RS, Pongracic J, Plaut M, Evans R, Visness CM, Walter M, Crain EF, Kattan M, Morgan WJ, Steinbach S, Stout J, Malindzak G, Smartt E, Mitchell H. Inner City Asthma Study: relationships among sensitivity, allergen exposure, and asthma morbidity. J Allergy Clin Immunol. 2005; 115(3):478-85. [PubMed: 15753892]

32. Sarpong SB, Hamilton RG, Eggleston PA, Adkinson NF. Socioeconomic status and race as risk factors for cockroach allergen exposure and sensitization in children with asthma. J Allergy Clin Immunol. 1996; 97(6):1393-401. [PubMed: 8648037]

33. Olmedo O, Goldstein IF, Acosta L, Divjan A, Rundle AG, Chew GL, Mellins RB, Hoepner L, Andrews H, Lopez-Pintado S, Quinn JW, Perera FP, Miller RL, Jacobson JS, Perzanowski MS. Neighborhood differences in exposure and sensitization to cockroach, mouse, dust mite, cat, and dog allergens in New York City. J Allergy Clin Immunol. 2011; 128(2):284-292.e7. [PubMed: 21536321]

34. Phipatanakul W, Eggleston PA, Wright EC, Wood RA. Study NCI-CA. Mouse allergen. II. The relationship of mouse allergen exposure to mouse sensitization and asthma morbidity in inner-city children with asthma. J Allergy Clin Immunol. 2000; 106(6):1075-80. [PubMed: 11112889]

35. Grant T, Aloe C, Perzanowski M, Phipatanakul W, Bollinger ME, Miller R, Matsui EC. Mouse Sensitization and Exposure Are Associated with Asthma Severity in Urban Children. J Allergy Clin Immunol Pract. 2016

36. Sarpong SB, Wood RA, Karrison T, Eggleston PA. Cockroach allergen (Bla g 1) in school dust. J Allergy Clin Immunol. 1997; 99(4):486-92. [PubMed: 9111492]

37. Kanchongkittiphon W, Sheehan WJ, Friedlander J, Chapman MD, King EM, Martirosyan K, Baxi SN, Permaul P, Gaffin JM, Kopel L, Bailey A, Fu C, Petty CR, Gold DR, Phipatanakul W. Allergens on desktop surfaces in preschools and elementary schools of urban children with asthma. Allergy. 2014; 69(7):960-3. [PubMed: 24750034]

38. Phipatanakul W, Bailey A, Hoffman EB, Sheehan WJ, Lane JP, Baxi S, Rao D, Permaul P, Gaffin JM, Rogers CA, Muilenberg ML, Gold DR. The school inner-city asthma study: design, methods, and lessons learned. J Asthma. 2011; 48(10):1007-14. [PubMed: 22010992]

39. Perzanowski MS, Rönmark E, Nold B, Lundbäck B, Platts-Mills TA. Relevance of allergens from cats and dogs to asthma in the northernmost province of Sweden: schools as a major site of exposure. J Allergy Clin Immunol. 1999; 103(6):1018-24. [PubMed: 10359880]

40. Tranter DC. Indoor allergens in settled school dust: a review of findings and significant factors. Clin Exp Allergy. 2005; 35(2):126-36. [PubMed: 15725182]

41. Tortolero SR, Bartholomew LK, Tyrrell S, Abramson SL, Sockrider MM, Markham CM, Whitehead LW, Parcel GS. Environmental allergens and irritants in schools: a focus on asthma. J Sch Health. 2002; 72(1):33-8. [PubMed: 11865797]

42. Custovic A, Green R, Taggart SC, Smith A, Pickering CA, Chapman MD, Woodcock A. Domestic allergens in public places. II: Dog (Can f1) and cockroach (Bla g 2) allergens in dust and mite, cat, 
dog and cockroach allergens in the air in public buildings. Clin Exp Allergy. 1996; 26(11):124652. [PubMed: 8955573]

43. Amr S, Bollinger ME, Myers M, Hamilton RG, Weiss SR, Rossman M, Osborne L, Timmins S, Kimes DS, Levine ER, Blaisdell CJ. Environmental allergens and asthma in urban elementary schools. Ann Allergy Asthma Immunol. 2003; 90(1):34-40.

44. Jacobs J, Borràs-Santos A, Krop E, Täubel M, Leppänen H, Haverinen-Shaughnessy U, Pekkanen J, Hyvärinen A, Doekes G, Zock JP, Heederik D. Dampness, bacterial and fungal components in dust in primary schools and respiratory health in schoolchildren across Europe. Occup Environ Med. 2014; 71(10):704-12. [PubMed: 25035116]

45. Borràs-Santos A, Jacobs JH, Täubel M, Haverinen-Shaughnessy U, Krop EJ, Huttunen K, Hirvonen MR, Pekkanen J, Heederik DJ, Zock JP, Hyvärinen A. Dampness and mould in schools and respiratory symptoms in children: the HITEA study. Occup Environ Med. 2013; 70(10):681-7. [PubMed: 23775866]

46. Baxi SN, Muilenberg ML, Rogers CA, Sheehan WJ, Gaffin J, Permaul P, Kopel LS, Lai PS, Lane JP, Bailey A, Petty CR, Fu C, Gold DR, Phipatanakul W. Exposures to molds in school classrooms of children with asthma. Pediatr Allergy Immunol. 2013; 24(7):697-703. [PubMed: 24112429]

47. Huttunen K, Tirkkonen J, Täubel M, Krop E, Mikkonen S, Pekkanen J, Heederik D, Zock JP, Hyvärinen A, Hirvonen MR. Inflammatory potential in relation to the microbial content of settled dust samples collected from moisture-damaged and reference schools: results of HITEA study. Indoor Air. 2016; 26(3):380-90. [PubMed: 25967114]

48. Holst GJ, Høst A, Doekes G, Meyer HW, Madsen AM, Plesner KB, Sigsgaard T. Allergy and respiratory health effects of dampness and dampness-related agents in schools and homes: a crosssectional study in Danish pupils. Indoor Air. 2016; 26(6):880-891. [PubMed: 26643593]

49. Chen CH, Chao HJ, Chan CC, Chen BY, Guo YL. Current asthma in schoolchildren is related to fungal spores in classrooms. Chest. 2014; 146(1):123-134. [PubMed: 24676386]

50. Carreiro-Martins P, Papoila AL, Caires I, Azevedo S, Cano MM, Virella D, Leiria-Pinto P, Teixeira JP, Rosado-Pinto J, Annesi-Maesano I, Neuparth N. Effect of indoor air quality of day care centers in children with different predisposition for asthma. Pediatr Allergy Immunol. 2016; 27(3):299_ 306. [PubMed: 26663443]

51. Tischer C, Weikl F, Probst AJ, Standl M, Heinrich J, Pritsch K. Urban Dust Microbiome: Impact on Later Atopy and Wheezing. Environ Health Perspect. 2016; 124(12):1919-1923. [PubMed: 27232328]

52. Cavaleiro Rufo J, Madureira J, Paciência I, Aguiar L, Pereira C, Silva D, Padrão P, Moreira P, Delgado L, Annesi-Maesano I, Oliveira Fernandes E, Teixeira JP, Moreira A. Indoor fungal diversity in primary schools may differently influence allergic sensitization and asthma in children. Pediatr Allergy Immunol. 2017; 28(4):332-339. [PubMed: 28208225]

53. Perzanowski MS, Miller RL, Thorne PS, Barr RG, Divjan A, Sheares BJ, Garfinkel RS, Perera FP, Goldstein IF, Chew GL. Endotoxin in inner-city homes: associations with wheeze and eczema in early childhood. J Allergy Clin Immunol. 2006; 117(5):1082-9. [PubMed: 16675336]

54. Thorne PS, Mendy A, Metwali N, Salo P, Co C, Jaramillo R, Rose KM, Zeldin DC. Endotoxin Exposure: Predictors and Prevalence of Associated Asthma Outcomes in the United States. Am J Respir Crit Care Med. 2015; 192(11):1287-97. [PubMed: 26258643]

55. Sheehan WJ, Hoffman EB, Fu C, Baxi SN, Bailey A, King EM, Chapman MD, Lane JP, Gaffin JM, Permaul P, Gold DR, Phipatanakul W. Endotoxin exposure in inner-city schools and homes of children with asthma. Ann Allergy Asthma Immunol. 2012; 108(6):418-22. [PubMed: 22626594]

56. Jacobs JH, Krop EJ, de Wind S, Spithoven J, Heederik DJ. Endotoxin levels in homes and classrooms of Dutch school children and respiratory health. Eur Respir J. 2013; 42(2):314-22. [PubMed: 23100494]

57. Jacobs JH, Krop EJ, Borras-Santos A, Zock JP, Taubel M, Hyvarinnen A, Pekkanen J, Doekes G, Heederik DJ. consortium Hss. Endotoxin levels in settled airborne dust in European schools: the HITEA school study. Indoor Air. 2014; 24(2):148-57. [PubMed: 23927557]

58. Lai PS, Sheehan WJ, Gaffin JM, Petty CR, Coull BA, Gold DR, Phipatanakul W. School Endotoxin Exposure and Asthma Morbidity in Inner-city Children. Chest. 2015; 148(5):12511258. [PubMed: 26087201] 
59. Matsui EC. Environmental exposures and asthma morbidity in children living in urban neighborhoods. Allergy. 2014; 69(5):553-8. [PubMed: 24697316]

60. Hulin M, Caillaud D, Annesi-Maesano I. Indoor air pollution and childhood asthma: variations between urban and rural areas. Indoor Air. 2010; 20(6):502-14. [PubMed: 20846209]

61. Brandt EB, Myers JM, Ryan PH, Hershey GK. Air pollution and allergic diseases. Curr Opin Pediatr. 2015; 27(6):724-35. [PubMed: 26474340]

62. Gaffin JM, Petty CR, Hauptman M, Kang CM, Wolfson JM, Abu Awad Y, Di Q, Lai PS, Sheehan WJ, Baxi S, Coull BA, Schwartz JD, Gold DR, Koutrakis P, Phipatanakul W. Modeling indoor particulate exposures in inner-city school classrooms. J Expo Sci Environ Epidemiol. 2017; 27(5): 451-457. [PubMed: 27599884]

63. Gaffin JM, Hauptman M, Petty CR, Sheehan WJ, Lai PS, Wolfson JM, Gold DR, Coull B, Koutrakis P, Phipatanakul W. Nitrogen Dioxide Exposure in School Classrooms of Inner-City Children with Asthma. J Allergy Clin Immunol. 2017 (In Press).

64. Daisey JM, Angell WJ, Apte MG. Indoor air quality, ventilation and health symptoms in schools: an analysis of existing information. Indoor Air. 2003; 13(1):53-64. [PubMed: 12608926]

65. Godwin C, Batterman S. Indoor air quality in Michigan schools. Indoor Air. 2007; 17(2):109-21. [PubMed: 17391233]

66. Mendell MJ, Heath GA. Do indoor pollutants and thermal conditions in schools influence student performance? A critical review of the literature. Indoor Air. 2005; 15(1):27-52.

67. Zheng XY, Ding H, Jiang LN, Chen SW, Zheng JP, Qiu M, Zhou YX, Chen Q, Guan WJ. Association between Air Pollutants and Asthma Emergency Room Visits and Hospital Admissions in Time Series Studies: A Systematic Review and Meta-Analysis. PLoS One. 2015; 10(9):e0138146. [PubMed: 26382947]

68. McCormack MC, Breysse PN, Matsui EC, Hansel NN, Williams D, Curtin-Brosnan J, Eggleston P, Diette GB. Environment CfCAitU. In-home particle concentrations and childhood asthma morbidity. Environ Health Perspect. 2009; 117(2):294-8. [PubMed: 19270802]

69. Kingsley SL, Eliot MN, Carlson L, Finn J, MacIntosh DL, Suh HH, Wellenius GA. Proximity of US schools to major roadways: a nationwide assessment. J Expo Sci Environ Epidemiol. 2014; 24(3):253-9. [PubMed: 24496217]

70. Rabinovitch N, Strand M, Gelfand EW. Particulate levels are associated with early asthma worsening in children with persistent disease. Am J Respir Crit Care Med. 2006; 173(10):1098105. [PubMed: 16484676]

71. Cakmak S, Mahmud M, Grgicak-Mannion A, Dales RE. The influence of neighborhood traffic density on the respiratory health of elementary schoolchildren. Environ Int. 2012; 39(1):128-32. [PubMed: 22208751]

72. Khreis H, Kelly C, Tate J, Parslow R, Lucas K, Nieuwenhuijsen M. Exposure to traffic-related air pollution and risk of development of childhood asthma: A systematic review and meta-analysis. Environ Int. 2017; 100:1-31. [PubMed: 27881237]

73. Lindgren P, Johnson J, Williams A, Yawn B, Pratt GC. Asthma exacerbations and traffic: examining relationships using link-based traffic metrics and a comprehensive patient database. Environ Health. 2016; 15(1):102. [PubMed: 27809853]

74. Lemanske RF, Kakumanu S, Shanovich K, Antos N, Cloutier MM, Mazyck D, Phipatanakul W, Schantz S, Szefler S, Vandlik R, Williams P. Creation and implementation of SAMPRO : A school-based asthma management program. J Allergy Clin Immunol. 2016; 138(3):711-23. [PubMed: 27596707]

75. Hester LL, Wilce MA, Gill SA, Disler SL, Collins P, Crawford G. Roles of the state asthma program in implementing multicomponent, school-based asthma interventions. J Sch Health. 2013; 83(12):833-41. [PubMed: 24261517]

76. Pilotto LS, Nitschke M, Smith BJ, Pisaniello D, Ruffin RE, McElroy HJ, Martin J, Hiller JE. Randomized controlled trial of unflued gas heater replacement on respiratory health of asthmatic schoolchildren. Int J Epidemiol. 2004; 33(1):208-14. [PubMed: 15075170]

77. Jhun I, Gaffin JM, Coull BA, Huffaker MF, Petty CR, Sheehan WJ, Baxi SN, Lai PS, Kang CM, Wolfson JM, Gold DR, Koutrakis P, Phipatanakul W. School Environmental Intervention to 
Reduce Particulate Pollutant Exposures for Children with Asthma. J Allergy Clin Immunol Pract. 2017; 5(1):154-159.e3. [PubMed: 27641483]

78. Bernstein JA, Levin L, Crandall MS, Perez A, Lanphear B. A pilot study to investigate the effects of combined dehumidification and HEPA filtration on dew point and airborne mold spore counts in day care centers. Indoor Air. 2005; 15(6):402-7. [PubMed: 16268830]

79. Lignell U, Meklin T, Putus T, Rintala H, Vepsäläinen A, Kalliokoski P, Nevalainen A. Effects of moisture damage and renovation on microbial conditions and pupils' health in two schools--a longitudinal analysis of five years. J Environ Monit. 2007; 9(3):225-33. [PubMed: 17344947]

80. Meklin T, Potus T, Pekkanen J, Hyvärinen A, Hirvonen MR, Nevalainen A. Effects of moisturedamage repairs on microbial exposure and symptoms in schoolchildren. Indoor Air. 2005; 15(Suppl 10):40-7. [PubMed: 15926943]

81. Karlsson AS, Andersson B, Renström A, Svedmyr J, Larsson K, Borres MP. Airborne cat allergen reduction in classrooms that use special school clothing or ban pet ownership. J Allergy Clin Immunol. 2004; 113(6):1172-7. [PubMed: 15208601]

82. Karlsson AS, Renström A, Hedrén M, Larsson K. Allergen avoidance does not alter airborne cat allergen levels in classrooms. Allergy. 2004; 59(6):661-7. [PubMed: 15147452]

83. Phipatanakul W, Cronin B, Wood RA, Eggleston PA, Shih MC, Song L, Tachdjian R, Oettgen HC. Effect of environmental intervention on mouse allergen levels in homes of inner-city Boston children with asthma. Ann Allergy Asthma Immunol. 2004; 92(4):420-5. [PubMed: 15104193]

84. Sublett JL. Effectiveness of air filters and air cleaners in allergic respiratory diseases: a review of the recent literature. Curr Allergy Asthma Rep. 2011; 11(5):395-402. [PubMed: 21773748]

85. Dotterud LK, Van TD, Kvammen B, Dybendal T, Elsayed S, Falk ES. Allergen content in dust from homes and schools in northern Norway in relation to sensitization and allergy symptoms in schoolchildren. Clin Exp Allergy. 1997; 27(3):252-61. [PubMed: 9088651]

86. Munir AK, Einarsson R, Schou C, Dreborg SK. Allergens in school dust. I. The amount of the major cat (Fel d I) and dog (Can f I) allergens in dust from Swedish schools is high enough to probably cause perennial symptoms in most children with asthma who are sensitized to cat and dog. J Allergy Clin Immunol. 1993; 91(5):1067-74. [PubMed: 8491939]

87. Nalyanya G, Gore JC, Linker HM, Schal C. German cockroach allergen levels in North Carolina schools: comparison of integrated pest management and conventional cockroach control. J Med Entomol. 2009; 46(3):420-7. [PubMed: 19496408]

88. Jassal MS, Diette GB, Dowdy DW. Cost-consequence analysis of multimodal interventions with environmental components for pediatric asthma in the state of Maryland. J Asthma. 2013; 50(6): 672-80. [PubMed: 23614791] 


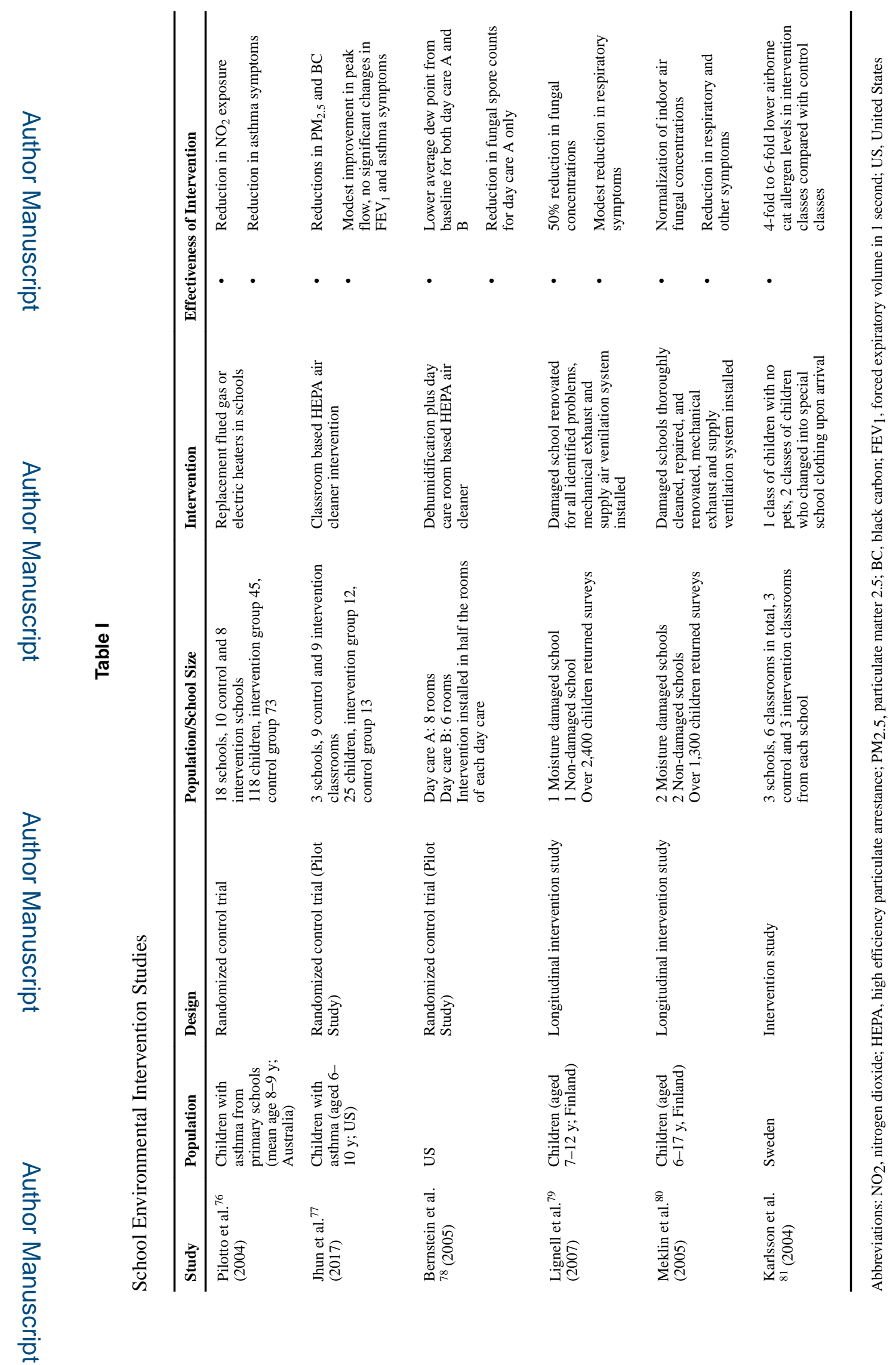

J Allergy Clin Immunol Pract. Author manuscript; available in PMC 2019 January 01. 